\title{
APLIKASI PENAMPIL DATA HASIL MONITORING SUHU DAN KELEMBABAN RUANGAN PADA WIRELESS SENSOR NETWORK
}

\author{
Wisnu Wiyardani ${ }^{1}$, Hartuti Mistialustina ${ }^{2}$ \\ 1,2Program Studi Teknik Elektro, Fakultas Teknik, Universitas Sangga Buana, \\ Bandung, Indonesia. \\ ${ }^{2}$ hartuti.mistialustina@google.com
}

\begin{abstract}
ABSTRAK
Tujuan dari perancangan aplikasi penampil data hasil monitoring suhu dan kelembaban ruangan pada Wireless Sensor Network (WSN) ini adalah agar terbangunnya sebuah aplikasi perangkat lunak Personal Computer (PC) berbasis Graphical User Interface (GUI) yang dapat menerima data hasil pemantauan suhu dan kelembaban dari modul Wireless Sensor Network (WSN) melalui komunikasi serial Recommended Standard (RS) 232 kemudian menampilkannya baik secara online maupun offline. Aplikasi ini sangat bergantung kepada perangkat keras kabel komunikasi serial RS232 sebagai penghubung dan pengirim data antara perangkat mikrokontroler Jennic JN5139 dalam modul WSN yang melakukan pengukuran langsung terhadap suhu dan kelembaban lebih dari 2 ruangan terhadap Personal Computer yang menampilkan data hasil pengukuran WSN. Bahasa pemrograman yang digunakan untuk aplikasi ini adalah Visual Basic 6. Data online yang dikirimkan dari modul WSN melalui RS232 ke Personal Computer kemudian disimpan ke dalam sebuah database Personal Computer menggunakan sistem database Microsoft Access 2003 untuk analisis secara offline monitoring yang ditampilkan baik dalam bentuk tabel maupun grafik.
\end{abstract}

Kata Kunci: RS-232, Jennic JN5139, Wireless Sensor Network (WSN), Visual Basic 6

\section{PENDAHULUAN}

Kemajuan teknologi saat ini sangat membantu dalam bidang informasi. Seperti halnya sensor, yang kini banyak digunakan untuk mendapatkan informasi yang diinginkan tanpa keterbatasan ruang dan waktu dengan mendayagunakan secara maksimal cara kerja sistem sensor tersebut. Kini untuk mendapatkan informasi misalkan tentang data data dari pemantauan suhu dan kelembaban dapat dilakukan dengan menggunakan banyak node sensor tersebar di tiap-tiap ruangan yang disebut dengan jaringan sensor. Jaringan sensor yang populer saat ini dengan konsumsi daya rendah, biaya yang rendah karena tanpa pengkabelan adalah Wireless Sensor Network (WSN).

Pengiriman data pengukuran pemantauan suhu dan kelembaban pada ruangan secara nirkabel ini menggunakan mikrokontroler Jennic JN5139 yang juga sebagai kendali akses kanal Radio Frekuensi (RF) guna komunikasi dengan node sensor lainnya yang terdekat yaitu node gateway atau Base Station Controller (BSC) . Node gateway atau BSC di sini bertugas sebagai pengumpul informasi hasil pantauan suhu dan kelembaban dari semua node sensor atau end device. Akan tetapi, node gateway memiliki kendala utama yaitu tidak adanya sistem penyimpanan data hasil pantauan online, dan tidak adanya kemampuan memonitor secara offline hasil pantauan suhu dan kelembaban dalam bentuk tabel atau grafik yang mana masih berbentuk led display.

Oleh karena itu, penulis merancang dan membangun suatu aplikasi penampil data hasil monitoring suhu dan kelembaban ruangan pada Wireless Sensor Network (WSN). Aplikasi ini menggunakan Personal Computer (PC) dalam bentuk tampilan Graphical User Interface (GUI) dengan tampilan yang lebih menarik dibanding led display. GUI di PC ini memiliki kemampuan menyimpan atau adanya memori data hasil pantauan baik yang online maupun yang terdahulu karena ada pembangunan database di dalamnya. Softwere PC Visual Basic 6 akan digunakan disini untuk rancang bangun database maupun GUI nya. Sedangkan agar PC dapat menerima data hasil pantuan suhu dan kelembaban dari perangkat 
mikrokontroler dalam modul WSN, maka digunakanlah kabel komunikasi serial Recommended Standard (RS) 232.

\section{LANDASAN TEORI}

\subsection{Sensor}

Cara objek melakukan proses pengumpulan informasi dari sebuah objek fisik ataupun proses kejadian alam lalu merubah informasi tersebut ke dalam bentuk sinyal listrik disebut Sensor [1]. Jadi Sensor adalah komponen yang dapat digunakan untuk mengkonversi suatu besaran fisis tertentu menjadi satuan analog listrik terkondisioning yang kemudian dikonversi menjadi sinyal digital agar dapat dibaca oleh suatu rangkaian elektronik seperti mikrokontroler.

Suhu bisa didefenisikan sebagai jumlah energi panas pada sebuah objek atau sistem. Sensor Suhu adalah sensor yang cara kerjanya merubah besaran suhu menjadi besaran listrik. Sensor suhu mendeteksi perubahan pada parameter fisik seperti hambatan listrik dan tegangan keluaran yang berbanding lurus dengan perubahan suhu [2]. Definisi kelembaban udara adalah perbandingan banyaknya kandungan uap air terhadap udara kering di atmosfer yang biasanya dinyatakan dalam satuan persen yang mana atmosfer merupakan campuran dari udara kering dan uap air.

\subsection{Wireless Sensor Network (WSN)}

Wireless sensor network (WSN) merupakan kumpulan dari beberapa node sensor tersebar di beberapa tempat atau ruangan untuk melakukan pengukuran terhadap besaran fisis tertentu yang kemudian mengandalkan 1 atau lebih node pusat sebagai pengumpul informasi dari hasil pengukuran semua node sensor. Node pusat juga sebagai pengkoordinir dan pengendali komunikasi antar node sensor dalam jaringan yang disebut sebagai node gateway atau Base Station Controller (BSC).

Protokol yang umum dan populer digunakan dalam komunikasi data antar sensor node dalam WSN saat ini adalah menggunakan sistem komunikasi zigbee. Zigbee disebut juga dengan Institute of Electrical and Electronics Engineers (IEEE) 802.15.4 menjadi topik penelitian yang hangat saat ini dalam teknologi komunikasi nirkabel jarak pendek. Teknologi Zigbee mengakomodir dua jenis topologi jaringan, yaitu single-hop dan multi-hop network [2]. Umumnya single-hop merupakan topologi star, sedangkan multi-hop merupakan topologi peer-to-peer terlihat pada gambar dibawah ini.

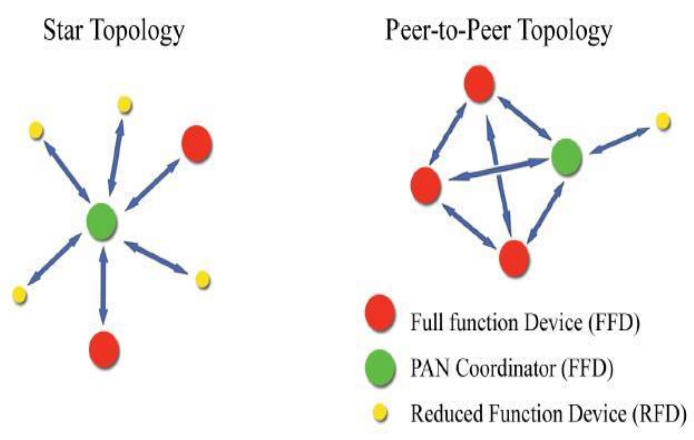

Gambar 1. Topologi Zigbee

Di dalam jaringan Zigbee harus ada satu koordinator yang juga disebut PAN(Personal Area Network) koordinator. PAN koordinator atau node gateway ini bertindak sebagai node pusat dan bertanggung jawab untuk memulai jaringan Zigbee dengan topologi star atau peer-to-peer [2]. Di dalam topologi star, komunikasi antar node harus melewati PAN koordinator (maksimal duahop). Topologi peer-to-peer, komunikasi antar node langsung menuju node tujuan tanpa melewati PAN koordinator jika node tujuan itu masih dalam coverage area node asal [2]. Topologi yang tergolong peer-topeer adalah mesh dan tree. Fitur yang dimiliki yaitu Zigbee bekerja pada range 10$100 \mathrm{~m}$, konsumsi daya rendah, data transfer yang real time, adanya fitur keamanan seperti Advanced Encryption Standard (AES) 128, manejemen penguncian, mendukung banyak node sensor dalam WSN, performa kerja dangan Signal Noise Ratio (SNR) rendah, dan Medium Access Controller (MAC) layer yang lebih sederhana dibanding MAC layer komunikasi wireless lainnya seperti pada IEEE 802.11x (LAN atau Bluetooth yang berdaya lebih besar).

Tujuan utama MAC layer protokol adalah untuk menekan borosnya daya akibat tumburan paket data, idle listening, pemanasan komponen, dan berlebihnya trafik data. Pengaturan akses ke medium memerlukan pertukaran kendali dan sinkronisasi informasi diantara node-node 
yang bersaing [3]. Pertukaran yang jelas dari banyaknya jumlah kontrol dan pensinkronisasian data paket node-node tersebut menimbulkan konsumsi daya yang signifikan.

\subsection{Komunikasi Serial RS232}

Komunikasi serial adalah cara yang memungkinkan dua peralatan berbeda protokol tegangannya dapat saling berkomunikasi. Disebut serial karena bit-bit data dikirim berurutan secara serial melalui saluran tunggal [4]. PC memiliki sebuah serial port yang disebut Communication Port (COM Port) digunakan untuk mengkoneksikan sebuah komputer terhadap dengan perangkat lain. Serial Port dikendalikan oleh chip khusus yang disebut UART (Universal Asynchronous Receiver Transmitter) suatu aplikasi yang menggunakan pin-pin pada serial port yang berbeda-beda sesuai akan kebutuhan fungsi yang diperlukan.

Metode komunikasi serial yang umum digunakan antara Personal Computer (PC) dengan modul perangkat mikrokontroler adalah komunikasi serial asinkron. Istilah asinkron ini biasanya digunakan untuk menggambarkan komunikasi data yang ditransmisikan sebentar-sebentar tidak berurutan bukan dalam bentuk aliran konstant [5]. Untuk dasar inilah, komunikasi asinkron kadang disebut start-stop transmisi [5]. Disamping, bit-bit khusus ditambahkan ke setiap kata agar mensinkronkan pengiriman dan penerimaan data, transmisi asinkron memungkinkan data dikirimkan tanpa pengirim harus mengirimkan sebuah sinyal clock ke penerima. Gambar 2 di bawah ini adalah bentuk data serial dikirimkan secara asinkron.

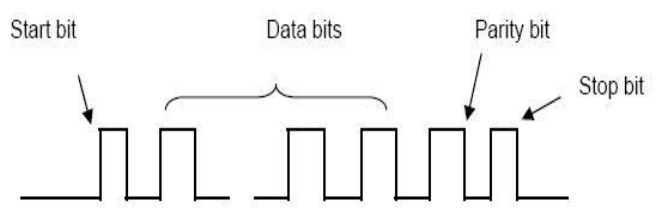

Gambar 2. Transmisi Data Serial [8]

Baudrate adalah pengukuran dari kecepatan pengiriman pada komunikasi asinkron. Baudrate mewakili sejumlah bit yang dikirimkan secara aktual melalui link serial [4]. Perhitungan Baudrate melibatkan perhitungan jumlah bit start, stop dan parity yang berlebihan yang dihasilkan dengan mengirimkan UART dan akan dihapus melalui penerimaan UART. Baudrate yang umum dipakai adalah 300,600, 1200, 2400, 9600, 115200 (bit/detik). Panjang data bit yang sering digunakan diantaranya adalah 4 , $5,6,7$, dan 8 bit.

Level tegangan pada mikrokontroler adalah -3 volt hingga +3 volt sedangkan pada Personal Computer adalah -15 volt hingga +15 volt . Oleh karena itu, spesifikasi level tegangan RS232 yang mengkonversi tegangan Mikrokontroler menjadi sesuai terhadap tegangan pada PC ditunjukkan pada Gambar 3. di bawah ini.

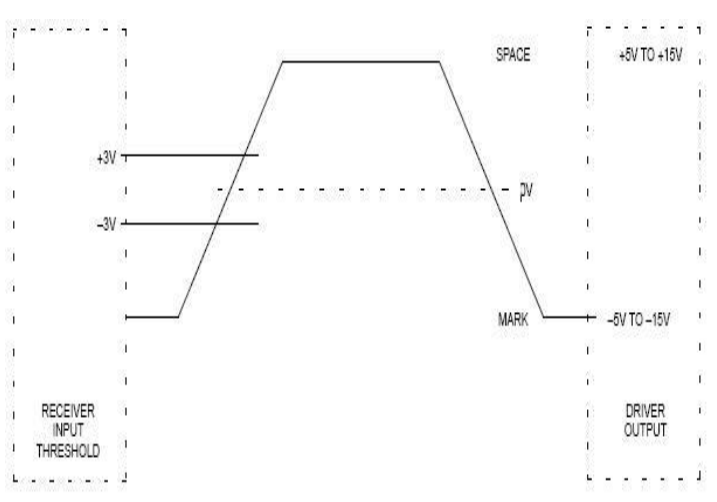

Gambar 3. Spesifikasi Logic Level Tegangan RS232

Perlu diingat bahwa untuk komunikasi RS232, tegangan level rendah yaitu antara -3 hingga -15 volt disebut sebagai sebuah logic 1 atau "Marking". Begitu juga dengan tegangan level tinggi antara +3 hingga +15 volt disebut sebagai logic 0 atau "Spacing". Standar RS232 juga membatasi laju rate pada output driver.

Format transmisi asinkron satu byte pada data RS232 yang ditransmisikan adalah 8 bit, sebelum data tersebut ditransmisikan maka akan diawali oleh start bit dengan logik 0 (0 Volt), kemudian 8 bit data dan diakhiri oleh satu stop bit dengan logika 1 (5 Volt).

\subsection{Visual Basic (VB) 6}

Microsoft Visual Basic 6.0 adalah bahasa pemrograman yang digunakan untuk membuat aplikasi Windows yang berbasis Grapical User Interface (GUI). Microsoft Visual Basic merupakan event-driven programming (pemrograman terkendali kejadian) artinya program menunggu sampai 
adanya respon dari pemakai berupa event atau kejadian tertentu (tombol diklik, menu dipilih, dan lain-lain) [6].

Beberapa kemampuan atau manfaat dari Visual Basic yaitu:

1. Untuk membuat program aplikasi berbasis Windows.

2. Untuk membuat objek-objek pembantu program seperti misalnya control ActiveX, file Help, aplikasi Internet.

3. Menguji program dan menghasilkan program berakhiran EXE yang bersifat executable atau dapat langsung dijalankan.

\subsubsection{Database Pada Visual Basic}

Database adalah kumpulan file-file yang saling berelasi, relasi tersebut biasanya ditunjukkan dengan kata kunci dari tiap filefile yang ada [7]. Hirarki Data:

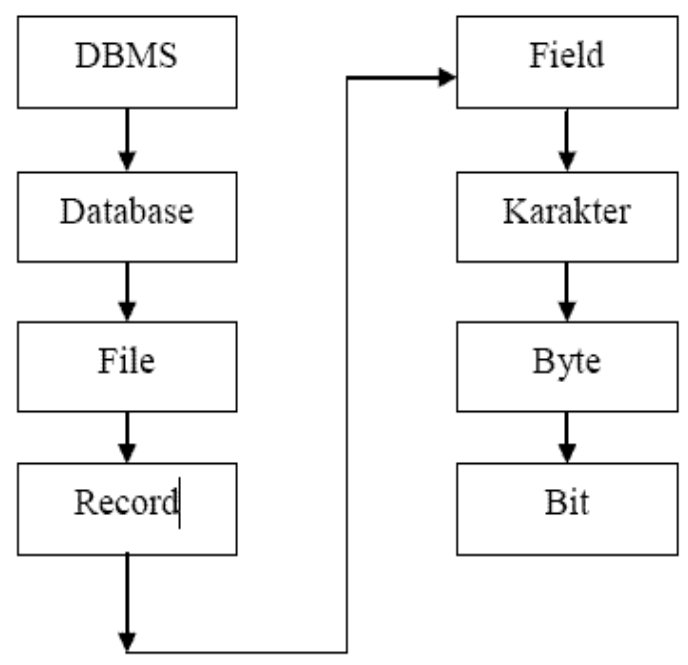

Gambar 4. Hirarkhi pembentukan Data

1. Database Management System (DBMS)

Diartikan sebagai suatu program komputer yang digunakan untuk memasukkan, mengubah, memanipulasi dan memperoleh data atau informasi dengan praktis dan efisien.

2. Database

Merupakan kumpulan file yang saling berhubungan satu dengan yang lainnya.

3. File

File terdiri dari record-record yang menggambarkan satu kesatuan data yang sejenis.

4. Record
Merupakan kumpulan elemen-elemen yang saling berkaitan menginformasikan tentang satu entity secara lengkap. Satu record mewakili satu data atau informasi tentang seseorang.

5. Field

Suatu field yang menggambarkan satu atribut dari record yang menunjukkan suatu item dari kata.

6. Karakter/byte

Karakter sebagai satuan data terkecil dikumpulkan menjadi field (kolom), kumpulan field membentuk sebuah record (baris), beberapa record disimpan dalam file (tabel), dan kumpulan file akan membentuk sebuah database.

7. Bit

Merupakan digit pada bilangan biner.

\subsubsection{Komunikasi Serial Pada Visual Basic 6.0}

Untuk pengaksesan port serial RS232 kita dapat mengaksesnya secara langsung menggunakan kontrol Microsoft Comm Control 6 (MSComm) yang telah disediakan Visual basic. Kontrol MSComm menyediakan fisilitas komunikasi antara program aplikasi yang kita buat dengan port serial untuk mengirim atau menerima data melalui port serial [8]. Setiap MSComm hanya menangani satu port serial sehingga jika kita ingin menggunakan lebih dari satu port serial harus digunakan MSComm lain. Jumlah properti pada MSComm sangat banyak, dan hanya beberapa properti yang perlu kita ketahui. Properti yang sering digunakan adalah :

1. CommPort

Digunakan untuk menentukan nomor port serial yang akan dipakai.

2. Setting

Digunakan untuk menset nilai baud rate, pariti, jumlah bit data, dan jumlah bit stop.

3. PortOpen

Digunakan untuk membuka ataupun menutup port serial yang dihubungkan dengan MSComm ini.

4. Input

Digunakan untuk mengambil data string yang ada pada buffer penerima.

5. Output

Digunakan untuk menulis data string pada buffer kirim. 


\section{PERANCANGAN}

\subsection{Perancangan Perangkat Keras}

Untuk perancangan perangkat keras guna perancangan perangkat lunak online offline monitoring suhu dan kelembaban ruangan pada WSN menggunakan jaringan WSN topologi star sebagaimana ditunjukkan pada Gambar 5. dibawah ini.

Dari gambar tersebut untuk memulai membentuk sebuah jaringan, koordinator bertugas untuk memulai jaringan dan akan mencari kanal radio yang sesuai. Setelah memilih kanal, koordinator memulai jaringan dengan mengidentifikasikan jaringan dengan Personal Area Network Identifier (PAN ID) dan siap merespon permintaan dari node lain untuk bergabung. Sedangkan End-Device dapat bergabung dengan jaringan yang telah terbentuk oleh koordinator tadi dengan terlebih dahulu mencari kanal yang disediakan dan mengirimkan pesan ke koordinator untuk bergabung dengan jaringan. Setelah koordinator mengijinkan End-Device untuk bergabung terjadilah pengiriman data.

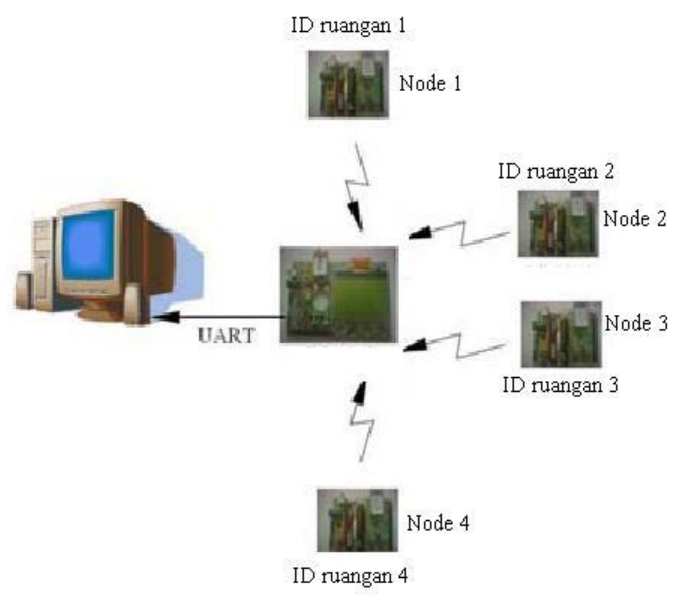

Gambar 5. Konfigurasi perancangan WSN topologi star

Kemampuan node sensor mengontrol dalam komunikasi mengirimkan data dengan node sensor lainnya, dan kemampuan node gateway mengkoordinir dalam mengontrol jaringan , serta menerima komunikasi data dari node sensor lainnya lalu melanjutkan pengiriman data hasil monitoring node-node sensor ke PC melalui kabel serial RS232 yang mana kesemuanya itu terlaksana karena terprogram di dalam IC Mikronkontroler Jennic JN5139 yang tertanam dalam setiap node sensor dan gateway WSN. Tiap-tiap IC Mikrokontroler node-node sensor dan gatewaynya harus diprogram terlebih dahulu dari PC computer dengan Bahasa $\mathrm{C} / \mathrm{C}++$ lalu decompile guna dihasilkan file biner untuk didownload ke masing-masing EEPROM IC node sensor dan gatewaynya.

\subsection{Mikrokontroler Jennic JN5139}

Sebagaimana ditunjukkan pada Gambar 6 dibawah ini bahwa WSN terbagi atas 5 bagian, yaitu communication device (transceiver), controller atau mikrokontroler, power suplai, Memory (memori eksternal), dan sensor (actuator).

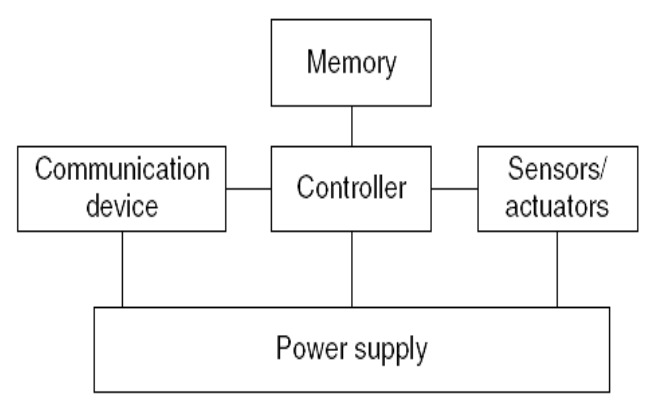

Gambar 6. Arsitektur WSN

$\begin{array}{lcr}\text { Transceiver } & \text { sebagai communication } \\ \text { device ini } & \text { berfungsi } & \text { untuk } \\ \text { menerima/mengirim } & \text { data dengan }\end{array}$ menggunakan protokol IEEE 802.15.4 atau IEEE $802.11 \mathrm{~b} / \mathrm{g}$ kepada device lain seperti concentrator, modem Wifi, dan modem RF. Mikrokontroler ini berfungsi untuk melakukan fungsi perhitungan, mengontrol dan memproses device-device yang terhubung dengan mikrokontroler. Power Source ini berfungsi sebagai sumber energi bagi sistem Wireless Sensor secara keseluruhan. External Memory berfungsi sebagai tambahan memory bagi sistem Wireless Sensor yang mana pada dasarnya sebuah unit mikrokontroler memiliki unit memory sendiri. Sensor berfungsi untuk men-sensing besaran-besaran fisis yang hendak diukur. Sensor adalah suatu alat yang mampu untuk mengubah suatu bentuk energi ke bentuk energi lain. Dalam hal ini adalah mengubah dari energi besaran yang diukur menjadi energi listrik yang kemudian diubah oleh Analog Digital Converter (ADC) menjadi deretan pulsa terkuantisasi yang kemudian bisa dibaca oleh mikrokontroler. 
Mikrokontroler JN5139 merupakan sebuah mikrokontroler nirkabel yang dirancang khusus untuk aplikasi yang menggunakan standar IEEE802.15.4 pada pita frekuensi 2,4 sampai 2,5 $\mathrm{GHz}$. Mikrokontroler JN5139 merupakan keluaran dari Jennic, yang di dalamnya merupakan solusi terintegrasi untuk aplikasi seperti: jaringan sensor nirkabel (wireless sensor network), otomasi untuk rumah dan bangunan, kendali jarak jauh (remote control), sistem industri, peralatan mainan dan telemetri. Mikrokontroler JN5139 memiliki arsitektur Reduced Instruction Set Computing (RISC) 32 bit yang di dalamnya sudah memiliki transceiver 2,4 GHz IEEE802.15.4, 192 kB ROM, 96 kB RAM, 128 bit akselerator enkripsi kode AES, empat input Analog Digital Converter (ADC) 12 bit, dua Digital Analog Converter (DAC) 11 bit, dua comparator, dua timer/counter, 3 sistem timer, dua UART, Serial Peripheral Interface (SPI) dengan lima pilihan dan satu antar muka untuk dua kabel serial. Gambar 3.3 menunjukkan tentang blok diagram dari mikrokontroler JN5139.

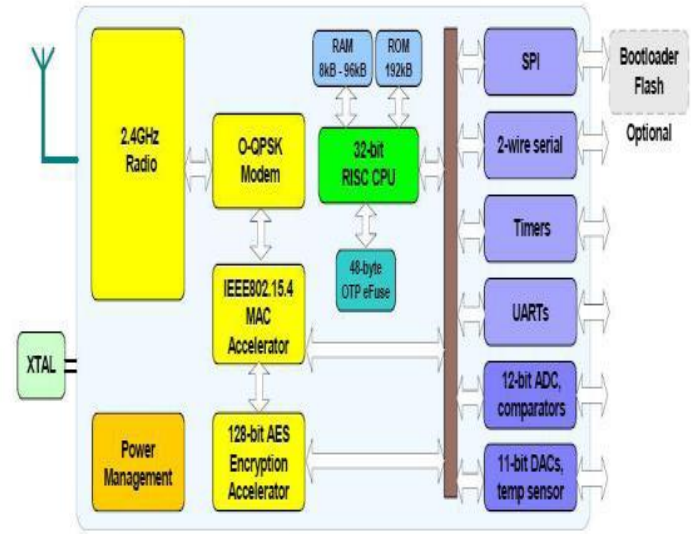

Gambar 7. Blok diagram mikrokontroler JN5139 [9]

\subsection{Perancangan Perangkat Lunak Komputer}

Untuk membuat sebuah program perangkat lunak antar muka untuk inisialisasi dan tampilan data maka langkah awalnya adalah melakukan analisasi sistem. Langkah selanjutnya membangun perangkat lunak dari hasil analisis sistem tadi, menjadi sebuah perangkat lunak yang siap untuk hubungkan ke aplikasi penampil data hasil monitoring suhu dan kelembaban ruangan pada wireless sensor network.

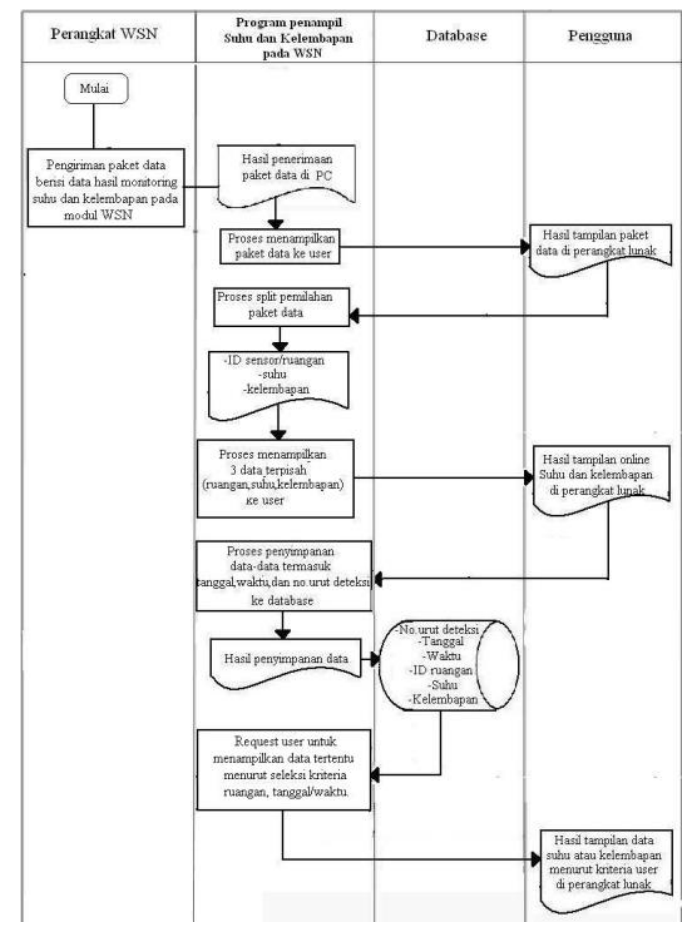

Gambar 8. Flow Map untuk Program Inisialisasi dan Tampilan Online Monitoring Suhu dan Kelembaban Ruangan pada WSN

Sedangkan prinsip-prinsip yang digunakan dalam merancang sebuah perangkat lunak antar muka adalah sebagai berikut :

1. Merefleksikan model mental pengguna, artinya model mental berasal dari kombinasi pengalaman dunia nyata, pengalaman dari software lain dan penggunaan komputer secara umum.

2. Explicit and Implicid action, artinya memberikan petunjuk dan kesan visual untuk memanipulasi objek.

3. Direct manipulation, artinya pengguna akan mendapatkan dampaknya dengan segera setelah melakukan aksi.

4. User control, artinya mengijinkan pengguna untuk mengontrol dan menginisialisasiaksi aksi dengan menampilkan beberapa level kontrol.

5. Feedback and communication, artinya adanya suatu pesan yang muncul jika terjadi kesalahan sehingga tidak membingungkan pengguna.

6. Consistency, artinya harus ada konsiostensi pada antar muka yang dibuat.

7. WYSIWYG, (What yuo see is what you get), artinya saaat melakukan pencetakan 
tidak ada perbedaan antara yang dilihat pengguna dengan outputnya.

8. Aesthic integrity, artinya informasi diorganisasi dengan baik dan konsisten dengan prinsip perancangn visual yang baik.

Adapun perancangan program perangkat lunak antar muka untuk inisialisasi dan tampilan aplikasi penampil data hasil monitoring suhu dan kelembaban ruangan pada wireless sensor network ini meliputi flow map, contex diagram (CD) dan data flow diagram (DFD). Gambar 8. menjelaskan tentang flow map diagram dimana pada flowmap tersebut menjelaskan tentang alur dari aliran data fisik, entitas yang terlibat dan kegiatan operasi yang berhubungan dengan aplikasi.

Sedangkan context diagram untuk antarmuka program perangkat lunak online monitoring suhu ruangan pada WSN dapat dilihat pada Gambar 9. berikut:

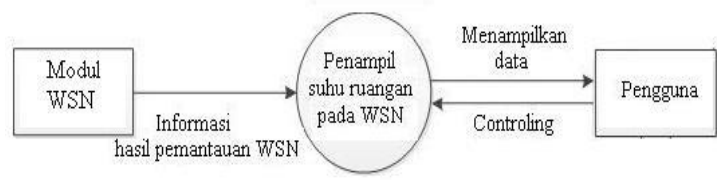

Gambar 9. Contex Diagram untuk Program Inisialisasi dan Tampilan Online Monitoring Suhu Dan Kelembaban Ruangan pada WSN

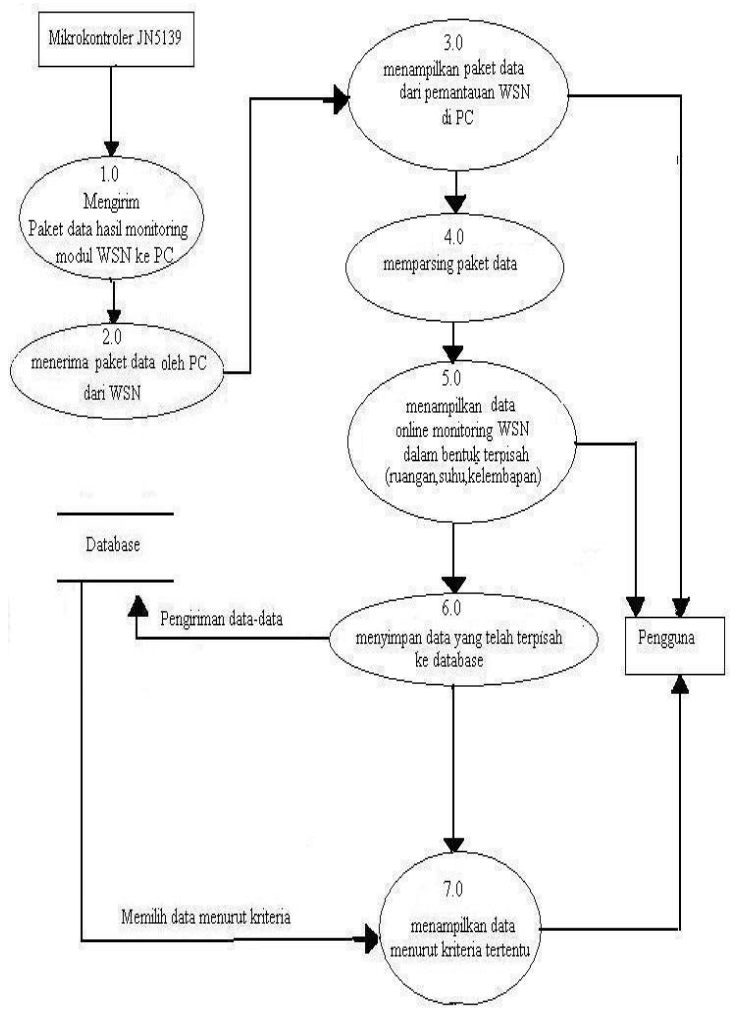

Gambar 10. DFD antarmuka program perangkat lunak online monitoring suhu dan kelembaban ruangan pada WSN

\subsection{Perancangan Paket Data}

Paket data yang dikirimkan dari WSN melalui interface serial komunikasi RS232 ke dalam program perangkat lunak komputer berupa 4 kemungkinan bentuk paket data yaitu:

1. $\mathrm{a} ; 01 ; 100 ; 100 ; \mathrm{b}$

2. $\mathrm{a} ; 02 ; 100 ; 100 ; \mathrm{b}$

3. $\mathrm{a} ; 03 ; 100 ; 100 ; \mathrm{b}$

4. $\mathrm{a} ; 04 ; 100 ; 100 ; \mathrm{b}$

Keterangan dari 4 bentuk paket data tersebut dijelaskan pada tabel dibawah ini.

Tabel 1. Arti huruf atau angka dalam 1 deretan paket data yang masuk

\begin{tabular}{|c|c|}
\hline $\begin{array}{l}\text { Paket } \\
\text { Data }\end{array}$ & Keterangan \\
\hline $\mathbf{a}$ & $\begin{array}{l}\text { Sebagai batas awal dalam } 1 \text { deretan } \\
\text { paket data yang masuk }\end{array}$ \\
\hline ; & $\begin{array}{l}\text { Sebagai pembatas antara jenis data } \\
\text { satu dengan jenis data lainnya dalam } 1 \\
\text { paket data yang masuk.Ada } 3 \text { jenis } \\
\text { data yang dikirimkan dalam } 1 \text { paket } \\
\text { data yang masuk yaitu jenis data } \\
\text { sebagai nomor ruangan, besarnya } \\
\text { suhu,dan kelembaban }\end{array}$ \\
\hline 01 & $\begin{array}{l}\text { Jenis data yang terletak setelah simbol } \\
\text {; yang pertama adalah sebagai nomor } \\
\text { yang digunakan untuk identitas ID } \\
\text { ruangan } 1 \text {. Ini menunjukkan bahwa } \\
\text { paket data yang masuk berasal dari } \\
\text { node sensor yang diletakkan pada } \\
\text { ruangan } 1 \text { melaporkan hasil pantauan } \\
\text { suhu dan kelembaban di ruangan } \\
\text { tersebut. }\end{array}$ \\
\hline 02 & $\begin{array}{l}\text { Jenis data yang terletak setelah simbol } \\
\text {; yang pertama adalah sebagai nomor } \\
\text { yang digunakan untuk identitas ID } \\
\text { ruangan } 2 \text {. Ini menunjukkan bahwa } \\
\text { paket data yang masuk berasal dari } \\
\text { node sensor yang diletakkan pada } \\
\text { ruangan } 2 \text { melaporkan hasil pantauan } \\
\text { suhu dan kelembaban di ruangan } \\
\text { tersebut }\end{array}$ \\
\hline 03 & $\begin{array}{l}\text { Jenis data yang terletak setelah simbol } \\
\text {; yang pertama adalah sebagai nomor } \\
\text { yang digunakan untuk identitas ID } \\
\text { ruangan 3. Ini menunjukkan bahwa } \\
\text { paket data yang masuk berasal dari } \\
\text { node sensor yang diletakkan pada } \\
\text { ruangan } 3 \text { melaporkan hasil pantauan } \\
\text { suhu dan kelembaban di ruangan } \\
\text { tersebut }\end{array}$ \\
\hline
\end{tabular}




\begin{tabular}{|c|c|}
\hline 04 & $\begin{array}{l}\text { Jenis data yang terletak setelah simbol } \\
\text {; yang pertama adalah sebagai nomor } \\
\text { yang digunakan untuk identitas ID } \\
\text { ruangan } 4 \text {. Ini menunjukkan bahwa } \\
\text { paket data yang masuk berasal dari } \\
\text { node sensor yang diletakkan pada } \\
\text { ruangan } 4 \text { melaporkan hasil pantauan } \\
\text { suhu dan kelembaban di ruangan } \\
\text { tersebut }\end{array}$ \\
\hline 100 & $\begin{array}{l}\text { Jenis data sebagai info laporan suhu } \\
\text { dan kelembapan yang diukur sensor } \\
\text { berdasarkan dimana sensor itu } \\
\text { diletakkan.100 sebagai nilai } \\
\text { maksimum hasil pengukurannya. } 100 \\
\text { yang pertama atau yang terletak } \\
\text { setelah simbol ; kedua adalah } \\
\text { parameter suhu ruangan yang } \\
\text { bersangkutan. 100 yang kedua atau } \\
\text { yang terletak setelah symbol ; ketiga } \\
\text { adalah parameter suhu ruangan yang } \\
\text { berasangkutan. Misal jika Jenis data } \\
\text { yang sebagai nomor ID nya adalah } 04 \\
\text { berarti melaporkan besarnya suhu dan } \\
\text { kelembaban yang berada di ruangan } \\
04 .\end{array}$ \\
\hline b & $\begin{array}{l}\text { Sebagai batas akhir penutup dalam } 1 \\
\text { deretan paket data yang masuk }\end{array}$ \\
\hline
\end{tabular}

Data hasil keluaran RS232 masuk ke komputer melalui port serial, yang kemudian akan diolah dengan menggunakan program Visual Basic 6.0.

\subsection{Implementaasi dan Hasil}

Implementasi aplikasi yang dirancang dengan Visual Basic 6.0 dapat memudahkan user untuk menggunakan aplikasi ini. Tampilan dan penggunaan yang mudah, menjadikan Visual Basic 6.0 software untuk perancangan aplikasi ini. Adapun beberapa tampilan dari aplikasi yang dirancang untuk berinteraksi dengan pemakai diantaranya:

\subsubsection{Form Home}

Ketika mengklik program, yang pertama kali muncul adalah form Home. Lalu user mempersilahkan bebas untuk memilih menu/form apa yang akan dimasuki berikutnya dengan cara mengklik menunya. Gambar di bawah ini adalah implementasi form Home.

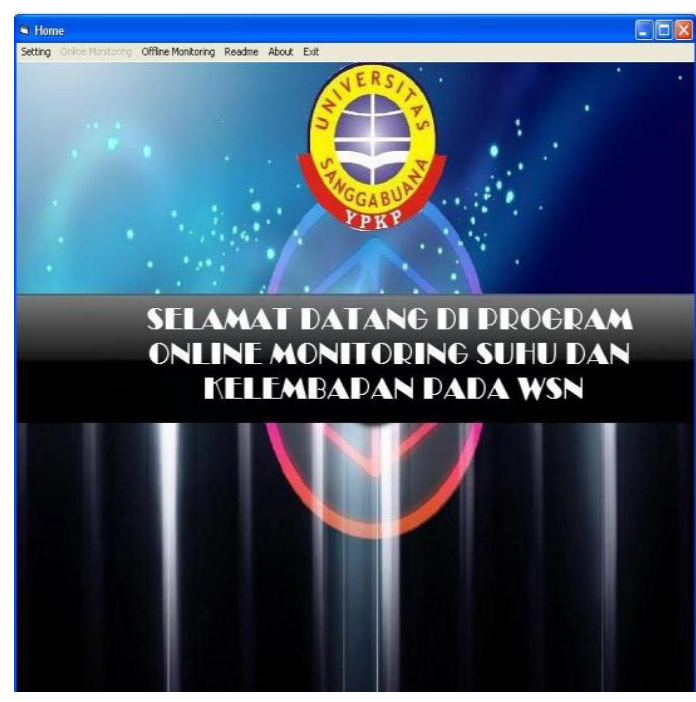

Gambar 11. Menu Home

\subsubsection{Form Setting}

Form online monitoring tidak akan aktif atau bisa dimasuki jika tidak masuk ke menu setting terlebih dahulu. Form setting berisi tentang pengaturan properti port yang digunakan oleh komunikasi serial dalam melaporkan data hasil pemantauan perangkat keras sensor-sensor di WSN ke perangkat lunak program ini. Di menu ini terdapat combolist tentang setting port yang harus dipilih. Setelah melakukan pemilihan port dengan menekan tombol "OK....Go To Online Monitoring " maka secara otomatis masuk ke menu Online monitoring. Tetapi, tombol dan pemilihan port tersebut tidak akan aktif jika kita tidak melakukan pengujian paket data dari WSN terlebih dahulu dengan mengklik tombol "Testing Dahulu"guna masuk ke menu "Testing". Untuk settingan property mscomm lainnya seperti baudrate, bit Parity, input Len, treshold, stop bit sudah disetting otomatis di dalam program ini melalui visual basic 6 . Untuk detailnya bisa dilihat pada gambar di bawah ini. Berikut adalah penjelasanpenjelasannya:

Pilihan port dan tombol "Ok...Go To Online Monitoring " masih disable, sehingga user harus masuk ke menu "Testing" terlebih dahulu dengan mengklik tombol "Testing Dahulu". 


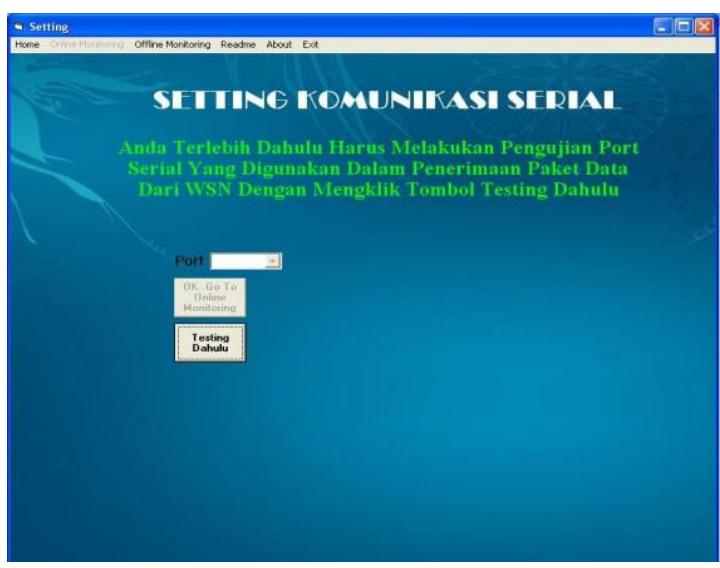

Gambar 12. Menu Setting

\subsubsection{Form Testing}

Menu Testing bertujuan untuk memastikan port mana yang digunakan dalam menerima data serial dari WSN dimana sekaligus menguji paket data yang masuk dari WSN agar memudahkan user dalam inisiasi pengiriman data antara modul WSN dan Personal Computer tanpa harus masuk ke My Computer-PropertiesHardware-Device.

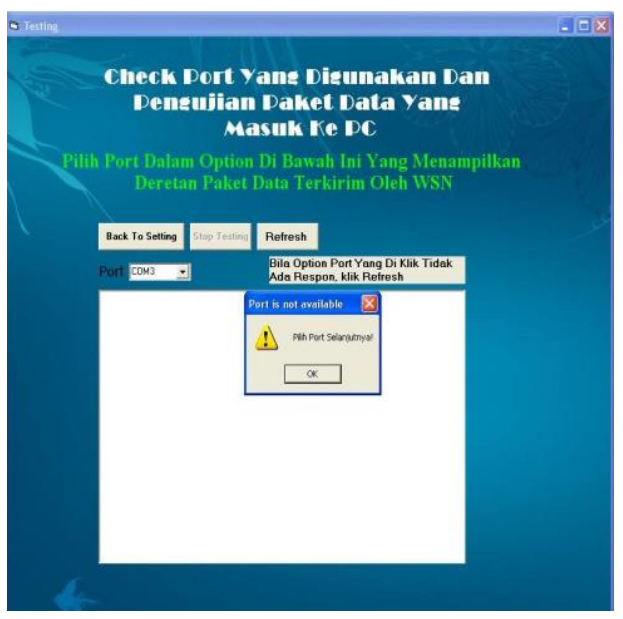

Gambar 13. Port serial yang digunakan bukan com 3

Manager untuk melihat port serial yang digunakan dan Hyper Terminal dalam pengujian inisiasi paket data yang masuk.

Untuk melakukan pengujian paket data yang masuk, user cukup memilih pilihan port yang ada dalam combo list di menu testing. Jika user salah memilih port yang digunakan misalkan port com3 maka akan muncul pesan seperti ditunjukkan pada gambar di bawah ini.
Jika port yang dipilih benar yaitu misalkan port com6, maka tampilan text akan muncul deretan paket data hasil monitoring suhu dan kelembaban dari modul WSN sebagaimana ditunjukkan pada gambar di bawah ini.

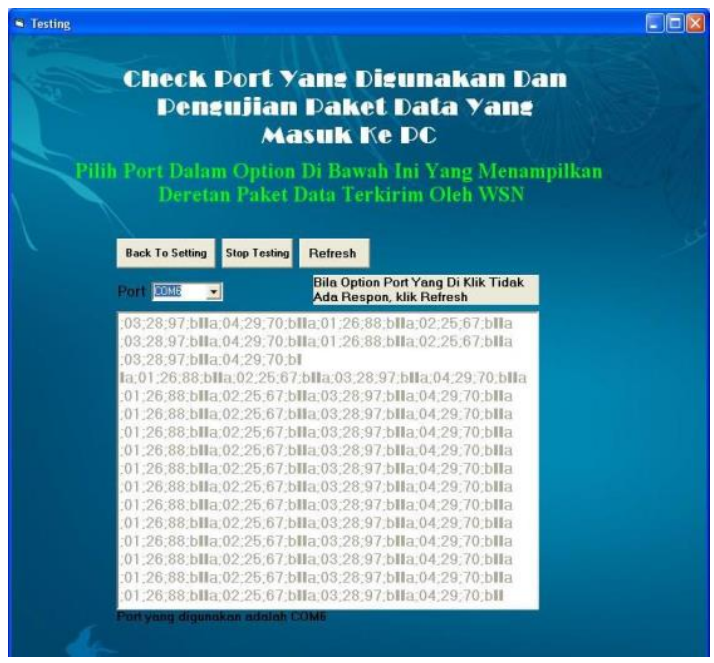

Gambar 14. Port com6 yang sebagai port serial penerima data dari WSN

Kita telah mengetahui bahwa port com6 yang digunakan. Lalu ketika kembali ke menu setting, pilihan port serial yang digunakan bisa dipilih dan tombol "OK...Go To Online Monitoring" bisa diklik sebagaimana ditunjukkan pada gambar di bawah ini.

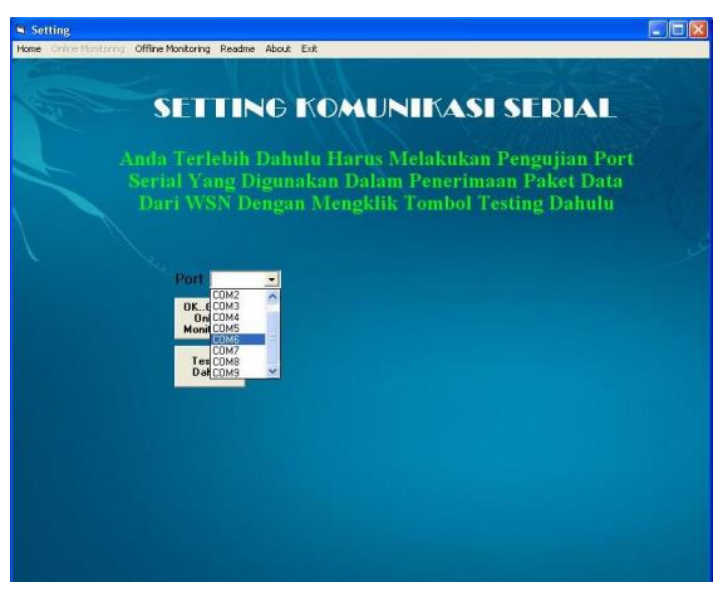

\section{Gambar 15. Pilihan port di menu setting}

Dari gambar di atas, setelah user memilih com6 berdasarkan testing tadi lalu mengklik tombol "OK...Go To Online Monitoring" maka masuk ke Menu Online Monitoring sebagaimana ditunjukkan pada Gambar 16. di bawah ini, 


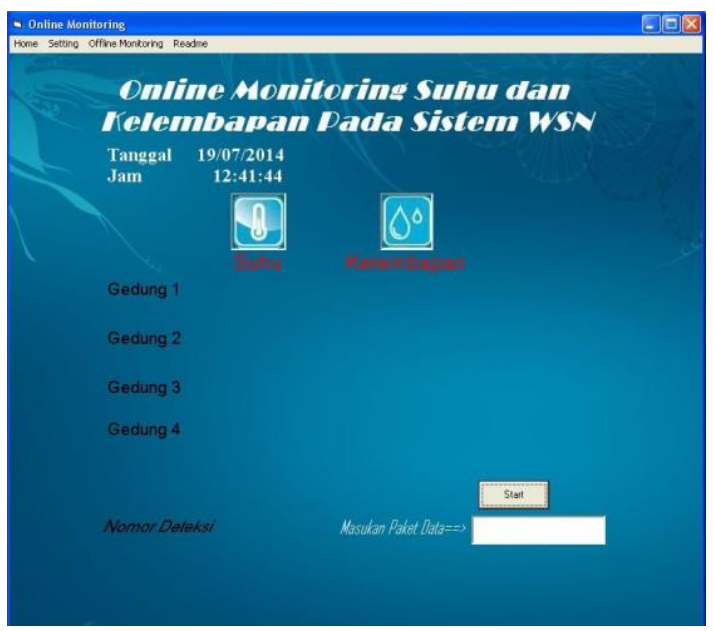

Gambar 16. Menu Online Monitoring

Untuk memulai proses online monitoring, user tinggal mengklik tombol "Start". Diketahui bahwa dari menu testing tadi, port serial yang digunakan adalah com6 . Jika ternyata di menu setting yang dipilih adalah selain com6, maka setelah tombol "Start" diklik pada menu online monitoring muncul pesan kesalahan seperti ditunjukkan pada Gambar 17 di bawah ini.

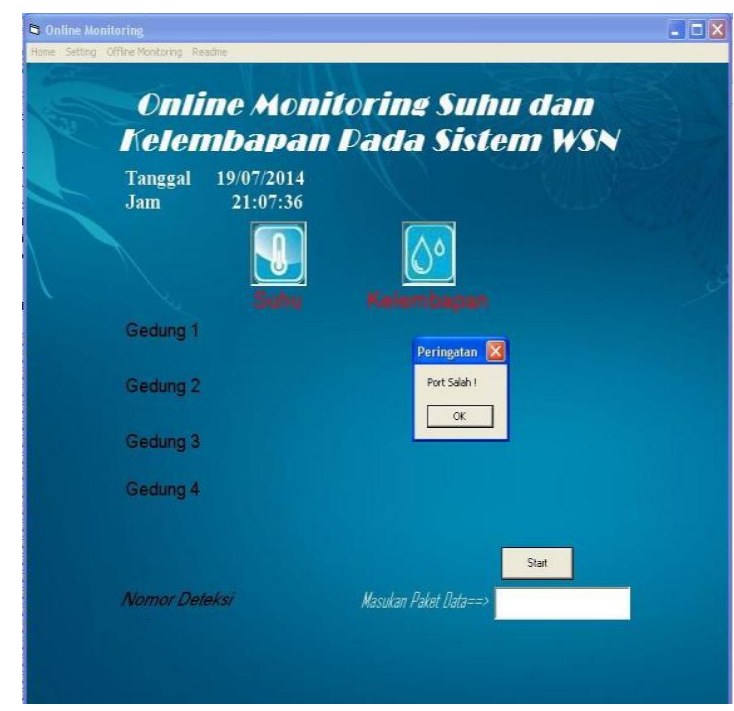

Gambar 17. Pesan kesalahan di menu Online Monitoring

Munculnya pesan tersebut di atas, maka secara otomatis user kembali ke menu setting untuk melakukan pemilihan ulang port. Kemudian kembali lagi ke menu online.

\subsubsection{Form Online Monitoring}

Setelah user memilih port yang benar ketika di menu setting tadi, lalu menekan tombol start di menu online monitoring maka terjadilah proses online monitoring suhu dan kelembaban seperti ditunjukkan pada gambar di bawah ini.

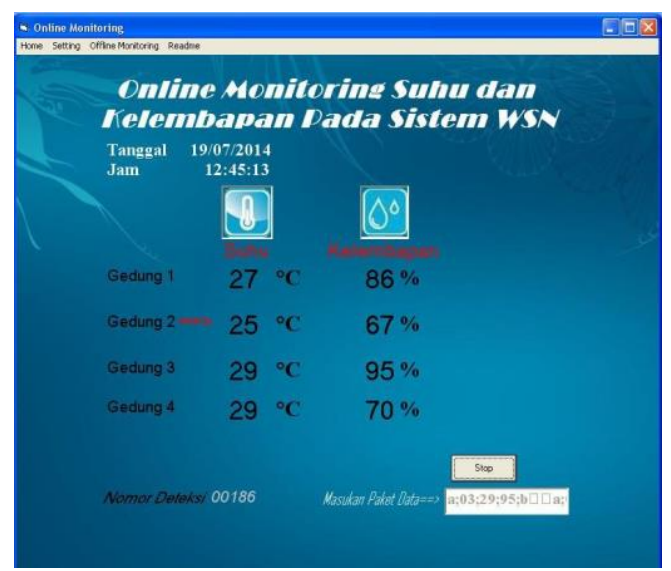

Gambar 18. Proses Online Monitoring Berlangsung

Text masukan paket data merupakan masukan paket data yang masuk dari modul WSN. Tanda panah warna merah misalkan berada di gedung 2 berarti update terkini data pelaporan pemantauan suhu dan kelembaban berasal dari sensor yang diletakkan di ruang gedung 2. Tanda panah warna merah bukan menunjukkan bahwa update data terbaru dari ruangan yang bersangkutan langsung disave ke dalam database. Tanda bahwa ada penyimpanan data-data hasil pantauan modul WSN yang terlebih dahulu diparsing ditampilkan ulang berdasarkan ruangan gedung 1 sampai dengan 4 adalah dengan perubahan nomor deteksi menurut interval waktu tertentu yang diatur oleh perancang. Misalkan nomor deteksi menunjukkan 00186 berarti database sudah menyimpan info suhu dan kelembaban sebanyak 186 data di tiaptiap ruangan gedung.

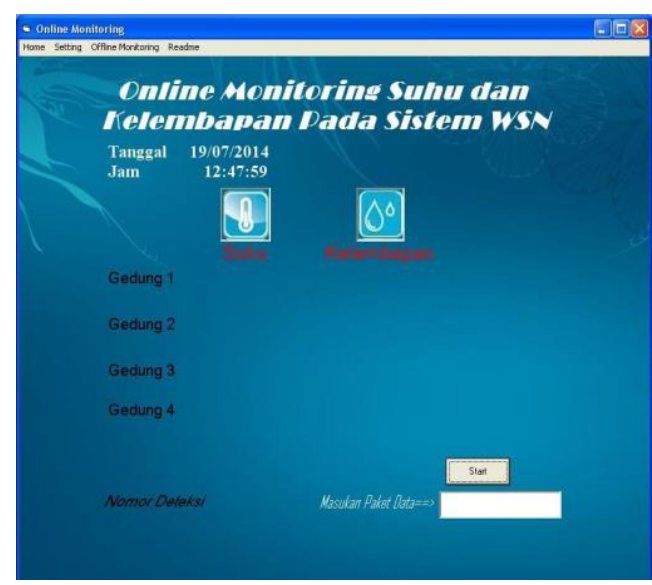

Gambar 19. Proses Online Monitoring Terhenti 
Jika user ingin menghentikan proses online monitoring, user cukup menekan tombol stop sehingga prosesnya terhenti sebagaimana ditunjukkan pada gambar di bawah ini yang mana info suhu dan kelembaban dari tiap-tiap ruangan gedung kosong termasuk info nomor deteksi dan text masukan paket data.

\subsubsection{Form Offline Monitoring}

Form Offline Monitoring bercabang menjadi 3 form lagi yaitu All record, Selected Record, dan Hapus record.

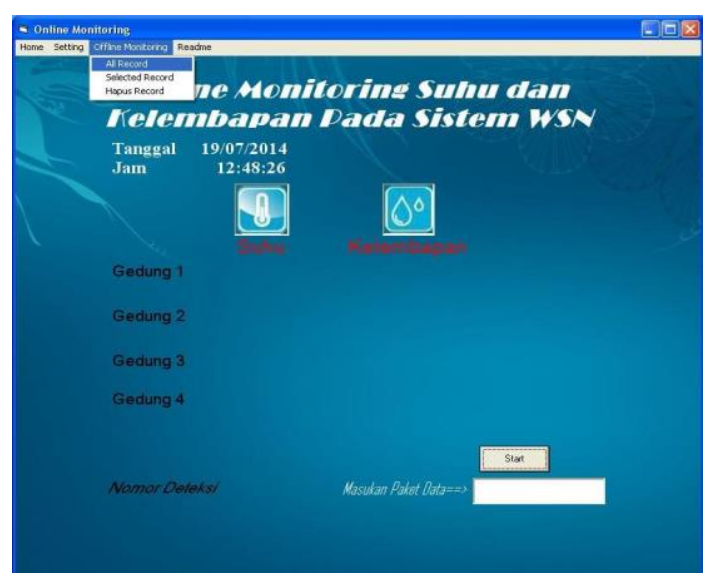

Gambar 20. Pilihan Menu dalam Menu Offline Monitoring

Untuk melihat semua record mulai dari pertama kali proses online monitoring hingga yang terakhir, user diharapkan mengklik all record sehingga muncul sebagaimana ditunjukkan pada gambar di bawah ini.

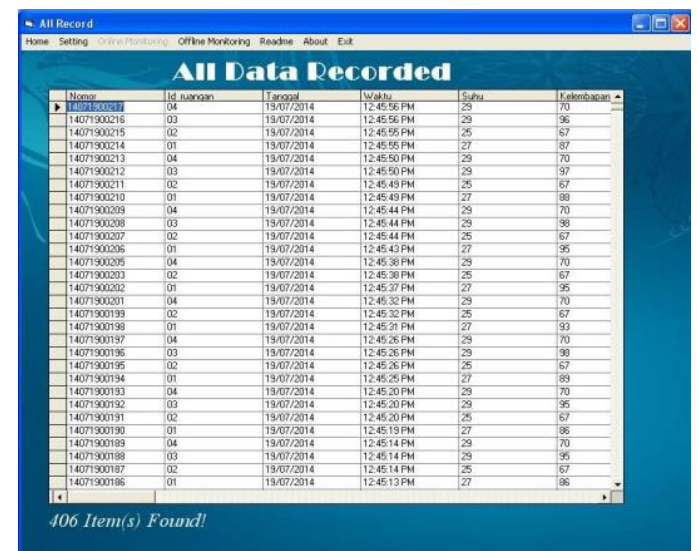

Gambar 21. Data Offline Monitoring Secara Keseluruhan

Bagi user yang ingin melihat data hasil pantauan modul WSN menurut kriteria permintaan user misalkan data yang ditampilkan hanya 1 ruangan saja, parameternya hanya suhu atau kelembaban saja maupun kedua-duanya,dan hanya berdasarkan seleksi tanggal-tanggal atau jamjam tertentu saja maka user diharapkan masuk ke menu selected record seperti ditunjukkan pada gambar di bawah ini.

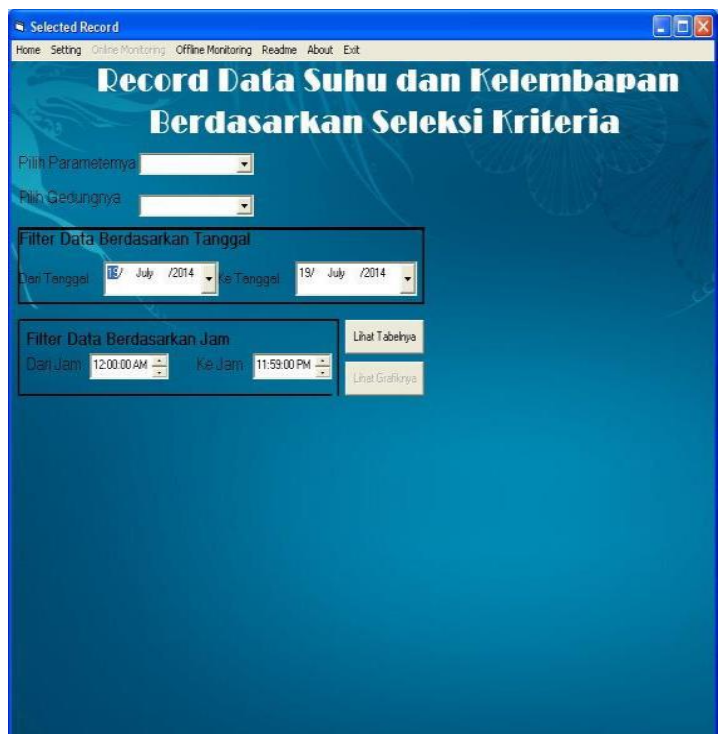

Gambar 22. Tampilan Menu Selected Record ketika di klik

Menu selected record tidak menampilkan isi tabel database ketika user masuk ke menu tersebut karena user belum melakukan penyeleksian data. Setelah user melakukan penyeleksian data dengan benar, maka akan muncul data database hasil monitoring suhu dan kelembaban baik berbentuk tabel maupun grafik sesuai kriteria keinginan user sebagaimana ditunjukkan pada gambargambar di bawah ini.

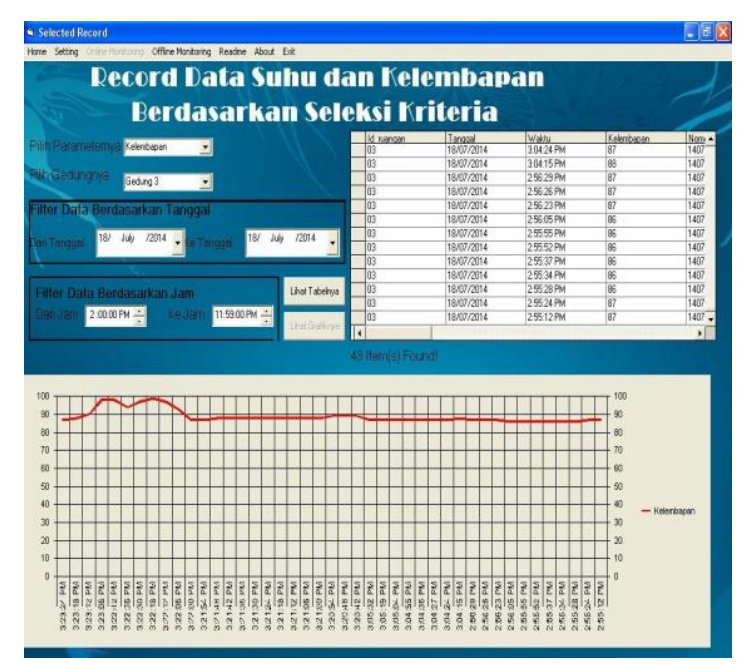

Gambar 23 Data offline monitoring dalam bentuk tabel dan Grafik 
Gambar 23 di atas menjelaskan tentang menampilkan data offline dari parameter kelembaban yang ada di gedung 3 dari tanggal 18 juli 2014 s/d 18 Juli 2014 atau 1 hari yang jamnya antara jam 14:00 hingga jam 23:59. Untuk tampilan data offline berbentuk garfik, sumbu vertikal $(\mathrm{Y})$ adalah besarnya nilai kelembaban. Sumbu horizontal (X) adalah waktunya. Untuk menampilkan 2 parameter sekaligus ditunjukkan pada Gambar 24. di bawah ini.

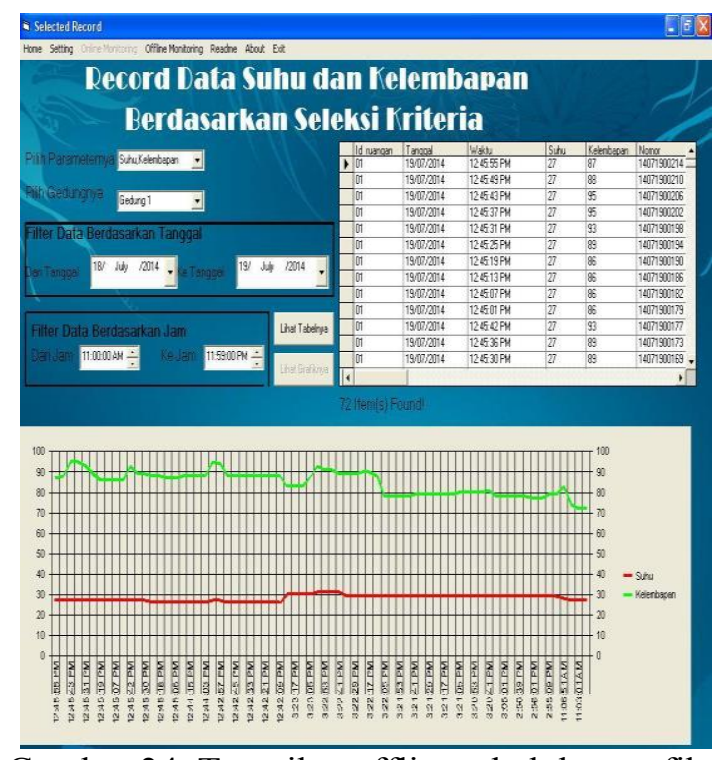

Gambar 24. Tampilan offline tabel dan grafik dari Suhu dan Kelembaban di gedung 1 untuk tanggal 18-19 Juli 2014 antara jam 11 pagi hingga jam 11.59 malam

Untuk menghapus record database baik secara data keseluruhan atau hanya tertentu saja menurut kriteria user, user diharapkan masuk ke menu hapus record yang berada di dalam menu offline monitoring sebagaimana ditunjukkan pada gambar di bawah ini.

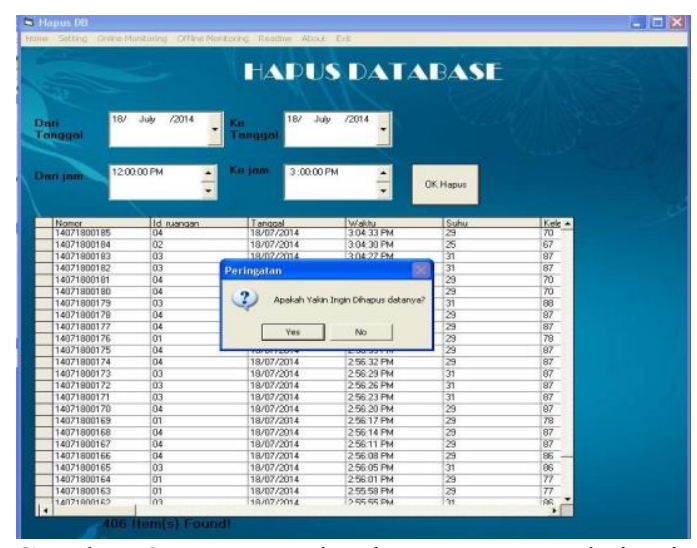

Gambar 25. Hapus database menurut kriteria
Untuk menghapus record tertentu, user cukup memilih option tanggal dan jamnya atau dengan mengklik satu-satu data dari tiap baris yang ada dalam tabel.

\subsubsection{Form Exit}

Form menu exit berfungsi untuk keluar dari program dengan muncul pesan konfirmasi terlebih dahulu apakah user yakin ingin keluar atau tidak. Permunculan pesan ini berfungsi untuk mencegah keluar program secara otomatis bila user tidak sengaja mengklik menu exit seperti ditunjukkan pada Gambar 26. di bawah ini.

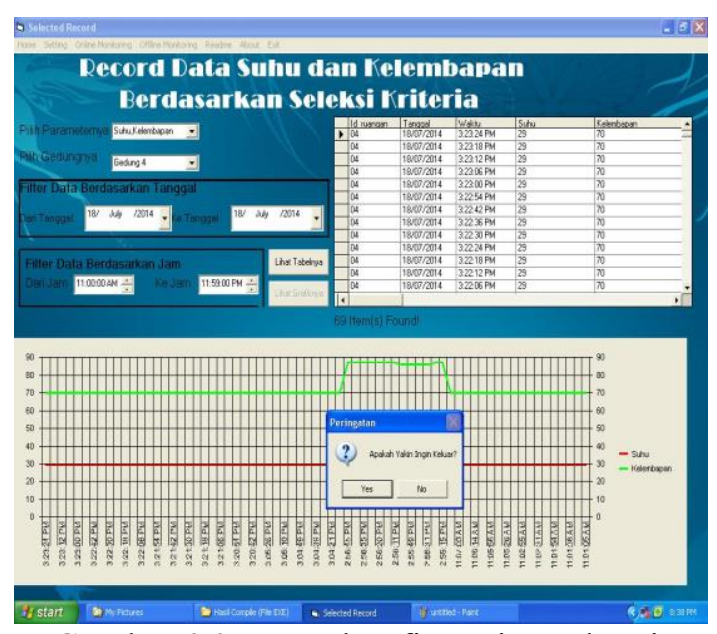

Gambar 26. Pesan konfirmasi untuk exit

\section{KESIMPULAN DAN SARAN}

\subsection{Kesimpulan}

Dari hasil perancangan dan pengujian, maka aplikasi perangkat lunak Personal Computer penampil data hasil monitoring suhu dan kelembaban ruangan pada Wireless Sensor Network (WSN) dapat berfungsi dengan baik dengan menggunakan Visual Basic 6. Hal ini terbukti dengan dapat diterima data dari hasil monitoring modul WSN melalui kabel komunikasi serial Recommended Standard (RS) 232 yang kemudian ditampilkan secara online. Selain itu, data hasil monitoring WSN dapat disimpan ke dalam sebuah database dengan menggunakan Microsoft Access 2003. Dengan adanya sistem database tersebut, maka aplikasi perangkat lunak Personal Computer penampil data hasil monitoring suhu dan kelembaban ruangan pada WSN dapat direalisasikan secara offline berupa tampilan tabel dan grafik. 


\subsection{Saran}

Dalam bagian ini penulis mencoba untuk memberikan saran-saran yang mungkin dapat dipertimbangkan dalam memanfaatkan aplikasi yang penulis buat, yaitu:

1. Dalam segi tampilan aplikasi untuk kedepannya dikembangkan agar lebih menarik, lebih mudah dipahami oleh user ,dan memiliki fitur menu yang lebih lengkap.

2. Dalam segi pengaksesan data hasil monitoring untuk kedepannya dikembangkan ke web server sehingga user yang berada jauh atau sangat jauh dari Personal Computer yang melakukan aplikasi ini bisa diakses melalui internet sehingga akan ada lebih dari 1 user dari berbagai tempat melakukan online dan offline monitoring ruangan pada Wireless Sensor Network.

3. Perlu adanya perancangan program dalam perangkat lunak Personal Computer untuk mengontrol modul Wireless Sensor Network dalam hal penghematan daya atau batere di tiap-tiap node Wireless Sensor Network yaitu mengontrol hanya node-node sensor tertentu saja yang melakukan pengukuran suhu dan kelembaban.
4. Data parameter yang diukur perlu ditambah yaitu misalkan penambahan data kualitas udara (kualitas $\mathrm{CO} 2$ ).

\section{DAFTAR PUSTAKA}

[1] A John Willey and Sons,Ltd,Publication , "Fundamentals of Wireless Sensor Networks Theory and Practice",2010

[2] "Sensor Technology Handbook"- By J.Wilson, Newnes - 2005

[3] A John Willey and Sons, Ltd, Publication, "Wireless Sensor Networks Technology, Protocols, and Applications"- By Kazem Sohraby, Daniel Minoli, Taieb Znati ,2007

[4] "www.efarabi.com/en/resarchnarticles/rs232 \%20serial\%20communication.pdf “

[5] "http://www.scribd.com/doc/7271897/Introd uction-to-Serial-Communication"

[6] "http://kangtofa.wordpress.com/2014/02/20/ $\mathrm{m}$ icrosoft-visual-basic-6-0/ “"

[7] "http://hamdansalam.blogspot.com/2012/05/ pengertian-database.html “

[8] "Microsoft Visual Basic Dalam Praktek " ,Yanuar Supardi , Penerbit Datakom Lintas Buana ,2003

[9] Harsito B1408703, Skripsi, "Sistem Komunikasi Data Zigbee pada Wireless Sensor Network untuk Pengukuran Suhu Ruangan", Universitas Sangga Buana YPKP Bandung 2010. 